\title{
The occurrence of spinocerebellar ataxias caused by dynamic mutations in Polish patients
}

\author{
Występowanie ataksji rdzeniowo-móżdżkowych spowodowanych mutacjami \\ dynamicznymi u pacjentów w populacii polskiej
}

Anna Sułek-Piątkowska', Elizbieta Zdzienicka', Maria Rakowicz², Wioletta Krysa', Marta Rajkiewicz', Walentyna Szirkowiec', Jacek Zaremba'

IZakład Genetyki, Instyłut Psychiatrii i Neurologii w Warszawie

2Zakład Neurofizjologii, Instyłut Psychiatrii i Neurologii w Warszawie

Neurologia i Neurochirurgia Polska 2010; 44, 3: 238-245

\begin{abstract}
Background and purpose: Autosomal dominant spinocerebellar ataxias (SCAs) belong to a group of neurodegenerative disorders usually of adult age at onset. Predominant clinical features are progressive ataxia, dysarthria, as well as pyramidal signs and polyneuropathy. Molecular analysis allows particular types of SCA to be distinguished. Genetic tests are applied in 10 types of SCA resulting from dynamic mutations: SCA1, SCA2, SCA3, SCA6, SCA7, SCA8, SCA10, SCA12, SCA17 and DRPLA.

Material and methods: DNA samples from 1598 patients with ataxia symptoms were analysed to establish the number of CAG/CTG repeats in respective genes excluding SCA10. Results: We diagnosed 224 cases of SCA1 (120 families) and 49 cases of SCA2 (23 families). Moreover, presymptomatic testing was done in 85 individuals from SCA1 families and for 21 cases from SCA2 families. An increased number of CTG repeats in the SCA8 gene was observed in 14 families and in 3 families a rare type of SCA, SCA17, was detected. Conclusions: Our data suggest that frequencies of some types of SCA in Poland are different from those in other European countries, with irregular distribution within the country. The most frequent types are SCA1 and SCA2. A striking feature of the Polish population is the lack of SCA3 - the most frequent type in Western Europe.
\end{abstract}

\section{Streszczenie}

Wstęp i cel pracy: Ataksje rdzeniowo-móżdżkowe (SCA) o dziedziczeniu autosomalnym dominującym należą do grupy chorób zwyrodnieniowych układu nerwowego, zazwyczaj o późnym wieku zachorowania. W obrazie klinicznym dominują postępująca ataksja i dyzartria, obserwuje się również objawy piramidowe i polineuropatię. Badania molekularne umożliwiają obecnie rozróżnienie poszczególnych typów SCA. Wykonuje się je w przypadkach 10 typów SCA, u podłoża których leżą mutacje dynamiczne zlokalizowane w odpowiednich genach: SCA1, SCA2, SCA3, SCA6, SCA7, SCA8, SCA10, SCA12, SCA17 i DRPLA.

Materiał i metody: Materiał do badań molekularnych stanowiły próbki DNA od 1598 pacjentów, u których obserwowano objawy ataksji. Analiza genetyczna polegała na ustaleniu liczby powtórzeń CAG/CTG we wszystkich wyżej wymienionych genach z wyjątkiem SCA10.

Wyniki: Stwierdzono 224 przypadki SCA1 w 120 rodzinach oraz 49 przypadków SCA2 (23 rodziny). Wykonano ponadto przedkliniczne molekularne badania u 85 osób z rodzin z SCA1 i u 21 osób z rodzin z SCA2. W 14 rodzinach stwierdzono nieprawidłową liczbę powtórzeń CTG w genie SCA8, a w 3 rodzinach bardzo rzadką postać ataksji - SCA17.

Wnioski: Uzyskane dane wskazują, że częstość występowania poszczególnych typów SCA w Polsce jest odmienna niż

Correspondence address: dr Anna Sułek-Piątkowska, Instytut Psychiatrii i Neurologii, Zakład Genetyki, ul. Sobieskiego 9, 02-957 Warszawa, e-mail: suleka@ipin.edu.pl

Received: 12.11.2009; accepted: 5.05.2010 
Key words: spinocerebellar ataxias (SCA), dynamic mutations, CAG repeats.

\section{Introduction}

Autosomal dominant cerebellar ataxias (ADCA) were previously termed olivo-ponto-cerebellar atrophy type 1 or olivo-ponto-cerebellar atrophy of Menzl. Currently, they are named spinocerebellar ataxias (SCAs). They create a heterogeneous group of genetic neurodegenerative diseases of the central nervous system (CNS) characterized by a broad range of clinical and neuropathological signs. Clinically, SCAs present most often as the cerebellar syndrome, pyramidal and extrapyramidal signs, as well as signs of peripheral neuropathy.

The heterogeneity of ADCA was the major problem when it came to developing a classification of these disorders. Attempts have been made to develop a classification based on the results of a small number of pathological studies. At the beginning, neither duration of the disease, nor the mode of inheritance was taken into account [1]. A clinically and neuropathologically based classification of ADCA was proposed by Harding in 1995 [2], and was subsequently modified by Stevanin et al. in 2000 [3].

As the molecular basis of SCAs was progressively unravelled, the above-mentioned classification became less and less useful, because particular types of SCA can be differentiated unequivocally with genetic testing only.

An important subgroup of SCAs consists of nine distinct types of SCA caused by dynamic mutations in the following genes (names of the diseases are provided in parentheses): ATXN1 (SCA1), ATXN2 (SCA2), ATXN3 (SCA3/MJD1), CACNA1A (SCA6), ATXN7 (SCA7), ATXN0S8 (SCA8), ATXN10 (SCA10), PPP2R2B (SCA12), TBP (SCA17), ATN1 (dentatorubral pallidoluysian atrophy, DRPLA) [4]. Mutations in all those SCA types lead to the expansion of the microsatellite repeats within particular genes. Expansion of the repeats and related instability are the basis for the typical tendency for the earlier age at onset and more severe course of the disease in subsequent generations, i.e. anticipation. Proteins with expanded polyglutamine stretch have abnormal conformation, tend to w innych krajach Europy, a ich rozmieszczenie na terenie kraju nierównomierne. Najczęściej występują SCA1 i SCA2, podczas gdy brak jest SCA3 - najbardziej rozpowszechnionego typu SCA w Europie Zachodniej.

Słowa kluczowe: ataksje rdzeniowo-móżdżkowe (SCA), mutacje dynamiczne, powtórzenia CAG.

sequestrate other proteins and may be visible as nuclear or cytoplasmic aggregates within neurons [4].

It is estimated that the prevalence of SCAs in general (without differentiation into subtypes) reaches about 3 per 100000 in the general population [4,5] but the prevalence of particular SCA subtypes differs among various populations. This probably results from the founder effect that can be found in studies of mutationrelated haplotypes. It is known, for example, that SCA3 and DRPLA are common in Japan and Portugal, SCA2 is frequent in Cuba [6-9] and Korea, and SCA6 is found most commonly in Germany and Japan $[10,11]$.

Clinical characteristics of SCAs caused by dynamic mutations are presented in Table 1. Additionally, broader characteristics of four SCAs occurring in the Polish population [12-14] are provided below.

Spinocerebellar ataxia type 1 (SCA1, OMIM\# 164400) is one of the commonest ADCA. Age at onset of symptoms ranges from 6 to 74 years, and the time from onset to death ranges from 12 to 38 years. Progressive gait disturbances and dysarthria are the earliest symptoms in the majority of patients. Other initial symptoms and signs include: ataxia and hypermetria of upper limbs, causing difficulties with writing, and nystagmus. Pyramidal syndrome is often observed, with spasticity and exaggerated deep tendon reflexes. Ataxia and dysmetria increase as the disease progresses. Marked weakness of all four limbs is noted. During the most advanced stage of the disease, ataxia increases markedly, and signs of brain stem damage appear, including atrophy and weakness of facial muscles, dysphagia and disordered breathing, as well as extrapyramidal signs, such as dystonia and chorea. Death usually results from the inability to cough and from respiratory failure $[12,15]$. Neuropathologically, SCA is characterized by cerebellar atrophy with the significant loss of Purkinje cells. Loss of neurons in the inferior olivary nucleus and in the nuclei of the third, tenth and twelfth cranial nerve is additionally seen [16].

The age at onset of symptoms in cases of spinocerebellar ataxia type 2 (SCA 2, OMIM\# 183090) ranges between 2 and 65 years. The disease begins with cere- 
Table 1. Typical clinical signs in spinocerebellar ataxias caused by dynamic mutations*

\begin{tabular}{|c|c|c|c|}
\hline $\begin{array}{l}\text { SCA } \\
\text { type }\end{array}$ & $\begin{array}{l}\text { Age at onset, } \\
\text { years mean } \\
\text { (range) }\end{array}$ & Characteristic clinical signs & OMIM \\
\hline SCA1 & $37(4-74)$ & $\begin{array}{l}\text { ataxia, dysarthria, nystagmus, saccadic slowing, ophthalmoplegia, spasticity, } \\
\text { peripheral neuropathy }\end{array}$ & 164400 \\
\hline $\mathrm{SCA} 2$ & $32(1-65)$ & $\begin{array}{l}\text { ataxia, dysarthria, saccadic slowing, hyporeflexia, tremor, dementia, parkinsonism, } \\
\text { peripheral neuropathy }\end{array}$ & 183090 \\
\hline $\mathrm{SCA} 3$ & $36(5-70)$ & $\begin{array}{l}\text { ataxia, dysarthria, nystagmus, eyelid retraction, diplopia, fasciculations of the tongue } \\
\text { and facial muscles, dystonia, parkinsonism, restless legs syndrome, polyneuropathy } \\
\text { with sensory disturbances }\end{array}$ & 109150 \\
\hline SCA6 & $52(30-71)$ & $\begin{array}{l}\text { pure ataxia, dysarthria, nystagmus, diplopia, rarely mild peripheral neuropathy, } \\
\text { pyramidal signs; benign course, often advanced age at onset }\end{array}$ & 183086 \\
\hline SCA7 & $35(0-70)$ & ataxia, dysarthria, vision loss due to retinopathy, saccadic slowing, pyramidal signs & 164500 \\
\hline SCA8 & $40(1-73)$ & ataxia, dysarthria, nystagmus, tremor & 603680 \\
\hline SCA10 & $36(26-45)$ & ataxia, dysarthria, nystagmus, epilepsy & 603516 \\
\hline SCA12 & $35(8-55)$ & ataxia, nystagmus, tremor, bradykinesia, hyperreflexia, cognitive disturbances & 604326 \\
\hline SCA17 & $33(6-48)$ & $\begin{array}{l}\text { ataxia, dysarthria, nystagmus, saccadic slowing, akinesia, dystonia, chorea, psychosis, } \\
\text { dementia, mutism, epilepsy }\end{array}$ & 600075 \\
\hline DRPLA & $40(0-62)$ & ataxia, myoclonus, epilepsy, choreoathetosis, psychosis, dementia & 125370 \\
\hline
\end{tabular}

bellar signs, including gait instability and speech disturbances, and hypotonia with concomitant painful muscle cramps. Saccadic slowing that precedes ophthalmoplegia is noted in many patients. Belal et al. [17] observed extrapyramidal signs (23\% of patients), myoclonus (38\%) and dementia (3\%) in addition to the typical cerebellar signs. Parkinsonian signs, including stiffness, bradykinesia, and postural or intentional tremor are alleviated with levodopa [18]. Axonal sensorimotor polyneuropathy was noted in most patients $[8,12,15]$. Neuropathological studies revealed marked loss of Purkinje cells. Neuronal atrophy in the olivary nuclei, pons, and cerebellum, as well as atrophy of the cerebral grey matter, were found. Significant demyelination was seen in the posterior column of the spinal cord. Less prominent alterations were noted within spinocerebellar tracts $[8,19]$.

Spinocerebellar ataxia type 8 (SCA8, OMIM\# 608768 ) is characterized by relatively slow progression. Gait instability increases gradually, followed by rest tremor and dysarthria [20]. Scanned and slowed speech is typical. Some patients exhibit nystagmus, dysmetria of saccades, and, rarely, ophthalmoplegia. Neuroimaging reveals atrophy of cerebellar hemispheres and ver$\operatorname{mis}[20]$.
Spinocerebellar ataxia type 17 (SCA17, OMIM\# 607136) is a rare SCA subtype. It presents usually with gait instability, progressive dementia and psychiatric symptoms, including depression, personality disorder, hallucinations and aggressive behaviour. These signs are followed by stiffness, bradykinesia, and, rarely, tremor. Because of similarity of some symptoms and signs, this SCA subtype is sometimes misdiagnosed as Huntington's disease. Magnetic resonance imaging (MRI) shows atrophy of the striatum and cerebellum; neuropathological studies confirm this notion and reveal neuronal loss in the striatum and putamen, as well as loss of Purkinje cells in the cerebellum. Less prominent neuronal loss in the frontal and temporal cortex has also been observed in some patients [21].

\section{Other subtypes of SCAs}

Other SCAs caused by dynamic mutations include SCA6, SCA7, SCA10, and SCA12 [22-26]. Only SCA6 is relatively frequent among them, especially in Germany and Japan; SCA10 is found mostly in Mexico, and SCA12 in India. Clinical signs of these SCAs are summarized in Table 1. 
Other autosomal dominant SCAs caused by mutations other than dynamic ones are not precisely characterized in terms of their molecular biology and clinical manifestations, because observations in those subtypes are based on several cases in single families only. Point mutations are the molecular basis of the disease in SCAs $4,5,11,13,14,15,16$, and 27 ; only the location of the gene within the chromosome is known for genes responsible for SCAs 18, 19, 20, 21, 22, 23, 24, 25, 26, 28, 29, and 30 . Axonal sensorimotor neuropathy accompanies ataxia in SCA4 and SCA25. Early onset is typical for SCA5. SCA11 has been described in two families only. Mental retardation is typical for SCA13, and epilepsy for SCA14, described in one Japanese family only. The term SCA9 has not been associated with any spinocerebellar ataxia and the name is reserved for the next identified and defined SCA subtype (according to Hereditary Ataxia Overview at www.geneclinics.org).

Effective treatment of SCA is lacking so far. Research related to the pathomechanism of these disorders and efforts aimed at development of treatment are ongoing.

The aim of this study was to present the results of molecular studies performed in Polish patients with suspected particular subtypes of SCAs caused by dynamic mutations.

\section{Material and methods}

DNA samples were collected from 1598 patients with ataxia who were diagnosed between 1998 and 2008 in genetic and neurological outpatient clinics or hospitalized in neurological departments of the Institute of Psychiatry and Neurology in Warsaw. Some DNA samples included in the present analysis were collected in various neurological outpatient clinics and departments in Poland and referred for genetic testing in the Department of Genetics, Institute of Psychiatry and Neurology.

Molecular studies consisted of analysis of the number of repeats in the following genes: ATXN1, ATXN2, ATXN3, CACNA1A, ATXN7, ATXN8OS, PPP2R2B, $T B P$, and $A T N 1$.

DNA was isolated from peripheral blood leukocytes using the phenol-chloroform method extraction method.

PCR reaction with amplification of the DNA region that contained the polymorphic CAG/CTG sequence within the studied genes was performed with pairs of primers specific for each gene. One primer within the pair of primers was labelled fluorescently. The following reports were used to establish $\mathrm{PCR}$ conditions and primer sequences: SCA1 - Orr et al. [27]; SCA2 - Pulst et al. [28]; SCA3 - Stevanin et al. [29]; SCA6 - Zhuchenko et al. [30]; SCA7 - David et al. [31]; SCA12 - Holmes et al. [26]; SCA17 - Koide et al. [21]; DRPLA - Nagafuchi et al. [32].

Electrophoretic separation of $\mathrm{PCR}$ products was visualized with an automated ABI PRISM 377 sequencer in $4 \%$ denaturing polyacrylamide gel; the size was established by comparison of the PCR product with the TAMRA350/500 size standard.

Patients' age at onset was established according to the data included in the medical records and in the referrals for the genetic studies; data were not complete. Place of birth and the present address were analysed in an attempt to characterize the Polish population in terms of prevalence of SCAs in particular regions of Poland.

Patients were informed of the indications for molecular analysis and provided written consent for the genetic testing and DNA samples collection in Department of Genetics, Institute of Psychiatry and Neurology, Warsaw. Patients gave their consent to publish the results of their genetic studies with preserved anonymity. Most of the discussed patients with SCA receive genetic counselling and neurological care from our Institute.

Statistical analysis of the results was performed with STATISTICA software. Descriptive statistics were performed; means and standard deviations were calculated.

\section{Results}

Two hundred and twenty-four cases of SCA1 were diagnosed in 120 families; 49 cases of SCA2 were found in 23 families. Additionally, studies in presymptomatic subjects were performed in 85 persons from the families affected by SCA 1 and in 21 subjects from the families affected by SCA2. Table 2 presents data obtained from 206 patients with SCA 1 because data related to age at onset were lacking in 18 patients.

Dynamic mutation was found in 26 persons (30.6\%) among presymptomatic adults from SCA1-affected families, and in 6 subjects (28.6\%) among presymptomatic adults from SCA2-affected families.

Statistical analysis revealed a significant inverse correlation between the number of CAG repeats and age at onset $(r=-0.66$ for patients with SCA 1 and $r=-0.67$ for patients with SCA2). This means that the age at onset is significantly determined by the number of CAG 
Table 2. Demographic data and molecular results of examined groups

\begin{tabular}{|lcccc|}
\hline & $\begin{array}{c}\text { SCA1 } \\
(\mathbf{n = 2 0 6 )}\end{array}$ & $\begin{array}{c}\text { SCA2 } \\
(\mathbf{n = 4 9 )}\end{array}$ & $\begin{array}{c}\text { SCA8 } \\
(\mathbf{n = 8})\end{array}$ & $\begin{array}{c}\text { SCA17 } \\
(\mathbf{n = 4 )}\end{array}$ \\
\hline Sex (F/M) & $115 / 91$ & $22 / 27$ & $4 / 4$ & $3 / 1$ \\
\hline Age at onset, years mean (SD) & $37.5(11.0)$ & $32.8(14.5)$ & $18.1(14.7)$ & 32.5 \\
\hline Age at examination, years mean (SD) & $43.9(12.5)$ & $42.9(16.7)$ & $38.5(23.0)$ & 44.0 \\
\hline $\begin{array}{l}\text { CAG/CTG repeat range (pathogenic alleles); } \\
\text { mean (SD) }\end{array}$ & $40-72$ & $36-52$ & $80-150$ & $48-53$ \\
\hline $\begin{array}{l}\text { Number of patients with confirmed mutation } \\
\text { but with incomplete demographic data, } \\
\text { who were not included in above calculations }\end{array}$ & $15.6(5.8)$ & $40.8(3.4)$ & $106.7(41.4)$ & 0 \\
\hline
\end{tabular}

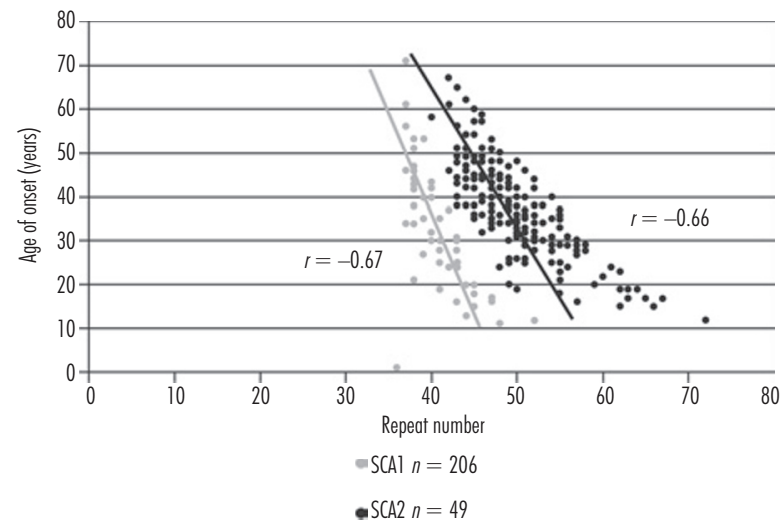

Fig. 1. The correlation of the CAG repeat number and the age of onset in SCAI and SCA2

repeats (in $66 \%$ and $67 \%$ for $\mathrm{SCA} 1$ and $\mathrm{SCA} 2$, respectively) (Fig. 1).

An abnormal number of CTA/CTG repeats in the ATXN8OS gene (SCA8) was found in 18 patients from 14 families (data provided in Table 2 are derived from 8 subjects who had both clinical signs and mutation within that gene).

A rare subtype of SCA, SCA17, was found in 4 patients from 3 families. One case of SCA 3 was also diagnosed in a female patient, whose symptomatic mother was of German descent.

Almost all SCA cases were found in families with several affected members (data related to the family history were lacking in 28 cases).

\section{Discussion}

According to the results of similar studies performed in European countries, the authors of the current paper expected that the most common SCAs in Europe, i.e. SCA1 and SCA3 [33], would also be prevalent in the Polish population. Therefore, molecular studies among Polish patients began with the diagnostics of SCA1 and SCA3. They revealed SCA1-affected families (a total of 120 pedigrees), but none of the remaining patients was diagnosed with SCA3.

Introduction of the SCA2 diagnostic method in 1999 enabled the diagnosis of expansion repeats in the SCA2 gene in 23 Polish families and also showed population differences in the frequency of particular SCAs in Poland [34].

Molecular studies in so far undiagnosed patients did not reveal any case of SCA6, SCA7, or DRPLA. Thus, two well-known SCAs - SCA1 and SCA2 - are predominant among studied Polish patients. Overall, mutations were found in 160 families (SCA1 - 75\%, SCA2 $-14.3 \%$, SCA $8-8.8 \%$, SCA $17-1.9 \%)$.

SCA 1 constitutes between $6 \%$ and $50 \%$ of ADCA type I and between $5 \%$ and $33 \%$ of all ADCA, depending on the population studied [5]. Higher proportions of SCA1 were noted in England [35], France [36], and Italy $[37,38]$, while lower proportions of SCA1 were noted among German [33], Russian [39], and Japanese patients [40].

Prevalence of SCA2 also depends on the ethnicity of studied patients. This SCA subtype is specifically prevalent in the Cuban province Holguin (41 per $100000)[8,9]$.

The frequency of SCA2 in German patients and in several large multiethnic groups (studies performed among Italian, Indian, and Chinese populations) was estimated to be $13-15 \%$ of all ADCA [15,41-43].

The proportion of SCA3/MJD in German [33], Chinese [44] and American [45] populations is estimated to reach $25-50 \%$ of all ADCA, while in Russian and 
South African populations this proportion is much lower. $\mathrm{SCA} 3 / \mathrm{MJC}$ is the most common ataxia in the Azores (1 per 3600 inhabitants) [46]. The one and only case of SCA3 diagnosed in a patient of German descent confirms the practical lack of SCA3 in the Polish population.

According to our findings, SCA 1 is more prevalent in Poland than in other countries, while SCA2 occurs with a frequency similar to some parts of Italy [37], where SCA1 was diagnosed in $30 \%$, and SCA2 in $21 \%$ of patients from families with clinically diagnosed SCA.

Further studies among Italian patients showed geographical diversity and more frequent occurrence of SCA1 in northern Italy (41\%), while other authors suggested that SCA2 occurs in $47 \%$ and SCA1 in $24 \%$ among 116 families from Central and Southern Italy, in whom the diagnosis of SCA was verified with molecular studies. These were the most common types of dominant ataxias in that population, while SCA6, SCA7, and DRPLA occurred in 2\%, 2\%, and $1 \%$, respectively [37].

Figure 2 shows the frequency of particular SCA subtypes among Polish cases with a family history suggestive of autosomal dominant mode of inheritance. Among all referred Polish patients, the available family history distinguished 286 families with ADCA, in whom the following SCAs were diagnosed: SCA1 $-42 \%$, $\mathrm{SCA} 2-8 \%, \mathrm{SCA} 8-4.9 \%$, SCA $17-1 \%$. The remaining $44.1 \%$ were families with ADCA in whom the mutation was not identified.

The Polish population seems to be similar to the Italian one, with the most prevalent SCA1 and SCA2.

The unexpected distribution of SCA subtypes in Poland led to the initiation of studies aimed at haplotype analysis to search for a founder effect (an ongoing study) and at the analysis of geographical distribution of SCA families. It seems that SCA1 is most prevalent in Mazowieckie, Łódzkie, Lubelskie, and Pomorskie voivodships (i.e. in central and eastern Poland), while SCA2 was observed more often in Śląskie, Świętokrzyskie, Mazowieckie, Łódzkie, and Lubelskie voivodships (i.e. in central and southern Poland). It should be noted, however, that this differential distribution may result from selection bias related to unequal access to specialized medical services throughout the country.

Other subtypes of SCA, i.e. SCA6, SCA7, SCA12, and DRPLA, were not found among the studied group of Polish patients. Those subtypes might be so rare in the Polish population that their detection would require a much larger group of patients. SCA6 was found to be one of the more common subtypes of inherited ataxias in Japan $[6,47]$; it also occurs in Spanish, German,

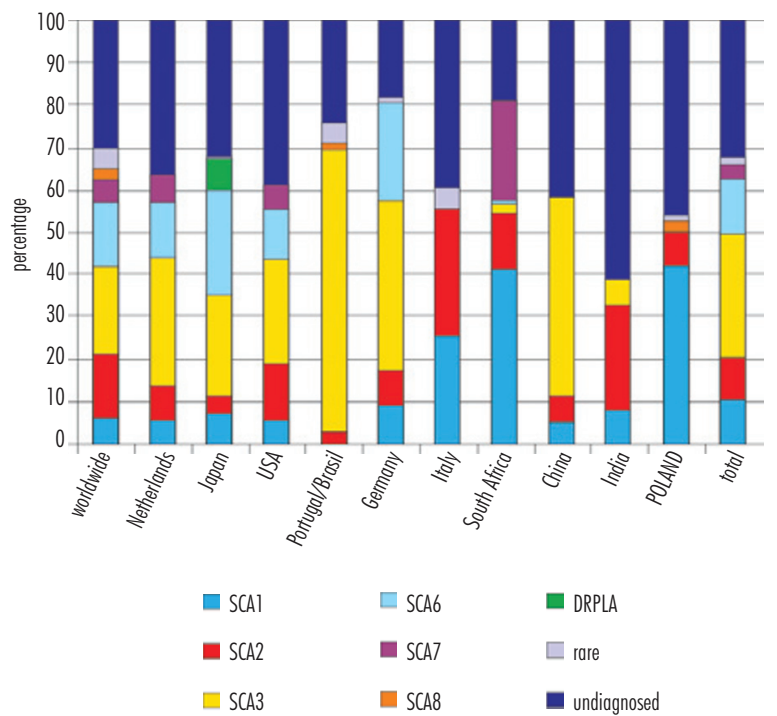

Fig. 2. Frequency of particular SCA subtypes in families with autosomal dominant spinocerebellar ataxia in various populations; data according to Schols et al. [4], modified by adding the results of the present study

Italian and Indian populations $[10,11,25,42]$. SCA7 is very rare, with a prevalence of less than $1: 100000$ in most populations (Australia, North America, Europe, China, India, Korea, South Africa, Taiwan) $[11,43,44,48,49]$. DPRLA is a rare neurodegenerative disorder, with the highest prevalence (6 per 100 000) in Japan; it is much less prevalent or even absent in Spanish, Italian, Chinese and South African populations $[7,37,42,43,51]$. SCA 17 is a rare SCA in all populations studied; we found it in 3 families in Poland.

According to the results, the following algorithm of the genetic testing was established in patients with ataxia, regardless of age or family history:

1. The first-line molecular studies should be directed to SCA1, SCA2, and SCA3 (the last one only because it is the most frequent SCA worldwide);

2. After exclusion of the above-mentioned SCA subtypes, genetic testing for other SCA subtypes, especially SCA8 and SCA17, should be considered;

3. Priority in molecular testing should be given to familial cases, especially those suggestive of autosomal dominant mode of inheritance.

\section{Conclusions}

1. Our data suggest that frequencies of some types of SCA in Poland are different from those in other European countries, with irregular distribution within the country. 
2. The most frequent types are SCA1 and SCA2.

3. A striking feature of the Polish population is the lack of $\mathrm{SCA} 3$ - the most frequent type in Western Europe.

\section{Acknowledgments}

This study was supported by:

Norwegian Fund - grant no. PL0076 (2006-2010); Sixth Framework Programme of EU - grant no. LSHM-CT-2004-503304 (2004-2009); Polish Ministry of Science - grant no. 3 PO5B 01924 (2003-2006).

The authors would like to thank all their colleagues - neurologists from outpatient clinics and departments - for their co-operation and patient referrals to the Institute of Psychiatry and Neurology in Warsaw.

The authors kindly acknowledge the role of "Ataxia" - Association of Families Affected by Spinocerebellar Ataxia in participation in research performed in the Institute of Psychiatry and Neurology.

\section{Disclosure}

Authors report no conflict of interest.

\section{References}

1. Holmes G. An attempt to classify cerebellar disease with a note on Marie's hereditary cerebellar ataxia. Brain 1907; 30: 466-489.

2. Harding AE. Inherited ataxias. Curr Opin Neurol 1995; 8: 306-309.

3. Stevanin G., Dürr A., Brice A. Clinical and molecular advances in autosomal dominant cerebellar ataxias: from genotype to phenotype and physiopathology. Eur J Hum Genet 2000; 8: 4-18.

4. Schols L., Bauer P., Schmidt T., et al. Autosomal dominant cerebellar ataxias: clinical features, genetics and pathogenesis. Lancet Neurol 2004; 3: 291-304.

5. Klockgether T. The clinical diagnosis of autosomal dominant spinocerebellar ataxias. Cerebellum 2008; 7: 101-105.

6. Watanabe H., Tanaka F., Matsumoto M., et al. Frequency analysis of autosomal dominant cerebellar ataxias in Japanese patients and clinical characterization of spinocerebellar ataxia type 6. Clin Genet 1998; 53: 13-19.

7. Silveira I., Coutinho P., Maciel P., et al. Analysis of SCA1, DRPLA, MJD, SCA2, and SCA6 CAG repeats in 48 Portuguese ataxia families. Am J Med Genet 1998; 81: 134-138.

8. Orozco Diaz G., Nodarse Fleites A., Cordovés Sagaz R., et al. Autosomal dominant cerebellar ataxia: clinical analysis of 263 patients from a homogenous population of Holquin, Cuba. Neurology 1990; 40: 1369-1375.

9. Velázquez Pérez L., Cruz G.S., Santos Falcón N., et al. Molecular epidemiology of spinocerebellar ataxias in Cuba:
Insights into SCA2 founder effect in Holguin. Neurosci Lett 2009; 454: 157-160

10. Schols L., Krüger R., Amoiridis G., et al. Spinocerebellar ataxia type 6: genotype and phenotype in German kindreds. J Neurol Neurosurg Psychiatry 1998; 64: 67-73.

11. Jin D., Oh M.R., Song S.M., et al. Frequency of spinocerebellar ataxia types 1, 2, 3, 6, 7 and dentatorubral pallidoluysian atrophy mutations in Korean patients with spinocerebellar ataxia. $J$ Neurol 1999; 246: 207-210.

12. Rakowicz M., Zdzienicka E., Poniatowska R., et al. Ataksja rdzeniowo-móżdżkowa typu 1 i 2 - porównanie oceny klinicznej, elektrofizjologicznej i rezonansu magnetycznego. Neurol Neurochir Pol 2005; 39: 263-275.

13. Niewiadomska M., Rakowicz M., Zdzienicka E., et al. Obraz elektrofizjologiczny w przypadkach SCA 1 - badania własne. Aktualn Neurol 2005; 5: 112-116.

14. Schmitz-Hübsch T., Coudert M., Bauer P., et al. Spinocerebellar ataxia types 1, 2, 3, and 6: disease severity and non-ataxia symptoms. Neurology 2008; 71: 982-989.

15. Filla A., De Michele G., Campanella G., et al. Autosomal dominant cerebellar ataxia type I. Clinical and molecular study in 36 Italian families including a comparison between SCA1 and SCA2 phenotypes. J Neurol Sci 1996; 142: 140-147.

16. Genetic instabilities and hereditary neurological diseases. Wells R.D., Warren S.T. (eds.). Academic Press, San Diego 1998.

17. Belal S., Cancel G., Stevanin G., et al. Clinical and genetic analysis of a Tunisian family with autosomal dominant cerebellar ataxia type 1 linked to the SCA2 locus. Neurology 1994; 44: 14231426.

18. Lastres-Becker I., Rüb U., Auburger G. Spinocerebellar ataxia 2 (SCA2). Cerebellum 2008; 7: 115-124.

19. Rüb U., Bürk K., Schöls L. Damage to the reticulosegmental nucleus of the pons in spinocerebellar ataxia type 1,2, and 3 . Neurology 2004; 63: 1258-1263.

20. Day J.W., Schut L.J., Moseley M.L., et al. Spinocerebellar ataxia type 8: clinical features in a large family. Neurology 2000; 55: 649657.

21. Koide R., Kobayashi S., Shimohata T., et al. A neurological disease caused by an expanded CAG trinucleotide repeat $\mathrm{i}$ the TATA-box binding protein gene: a new polyglutamine disease? Hum Mol Genet 1999; 8: 2047-2053.

22. Benton C.S., de Silva R., Rutledge S.L., et al. Molecular and clinical studies in SCA 7 define a broad clinical spectrum and the infantile phenotype. Neurology 1998; 51: 1081-1086.

23. Grewal R., Achari M., Matsuura T., et al. Clinical features and ATTCT repeat expansion in spinocerebellar ataxia type 10. Arch Neurol 2002; 59: 1285-1290.

24. Maschke M., Oehlert G., Xie T.D., et al. Clinical feature profile of spinocerebellar ataxia type 1-8 predicts genetically defined subtypes. Mov Disord 2005; 20: 1405-1412.

25. Arpa J., Cuesta A., Cruz-Martínez A., et al. Clinical features and genetic analysis of a Spanish family with spinocerebellar ataxia 6. Acta Neurol Scand 1999; 99: 43-47.

26. Holmes S., O'Hearn E., McInnis M.G., et al. Expansion of a novel CAG trinucleotide repeat in the 5' region of PPP2R2B is associated with SCA12. Nat Genet 1999; 23: 391-392. 
27. Orr H.T., Chung M.Y., Banfi S., et al. Expansion of an unstable trinucleotide CAG repeat in spinocerebellar ataxia type 1. Nat Genet 1993; 4: 221-225.

28. Pulst S.M., Nechiporuk A., Nechiporuk T., et al. Moderate expansion of a normally biallelic trinucleotide repeat in spinocerebellar ataxia type 2. Nat Genet 1996; 14: 269-276.

29. Stevanin G., Sousa P.S., Cancel G., et al. The gene for MachadoJoseph disease maps to the same $3-\mathrm{cM}$ interval as the spinal cerebellar ataxia 3 gene on chromosome 14q. Neurobiol Dis 1994; 1: 79-82.

30. Zhuchenko O., Bailey J., Bonnen P., et al. Autosomal dominant cerebellar ataxia (SCA6) associated with small polyglutamine expansions in the alpha 1A-voltage-dependent calcium channel. Nat Genet 1997; 15: 62-69.

31. David G., Abbas N., Stevanin G., et al. Cloning of the SCA 7 gene reveals a highly unstable CAG repeat expansion. Nat Genet 1997; 17: 65-70.

32. Nagafuchi S., Yanagisawa H., Sato K. Dentatorubral and pallidoluysian atrophy expansion of an unstable CAG trinucleotide on chromosome 12p. Nat Genet 1994; 6: 14-18.

33. Schöls L., Vieira-Saecker A.M., Schöls S., et al. Trinucleotide expansion within the MJD1 gene presents clinically as spinocerebellar ataxia and occurs most frequently in German SCA patients. Hum Mol Genet 1995; 4: 1001-1005.

34. Sulek A., Hoffman-Zacharska D., Zdzienicka E., et al. SCA8 repeat expansion coexists with SCA1 - not only with SCA6. Am J Hum Genet 2003; 73: 972-974.

35. Leggo J., Dalton A., Morrison P.J., et al. Analysis of spinocerebellar ataxia types $1,2,3$, and 6 , dentatorubralpallidoluysian atrophy, and Friedreich's ataxia genes in spinocerebellar ataxia patients in the UK. J Med Genet 1997; 34: 982-985

36. Khati C., Stevanin G., Durr A., et al. Genetic heterogenity of autosomal dominant cerebellar ataxia type 1. Clinical and genetic analysis of 10 French families. Neurology 1993; 43: 1131-1137.

37. Filla A., Mariotti C., Caruso G., et al. Relative frequencies of CAG expansions in spinocerebellar ataxia and dentatorubralpallidoluysian atrophy in 116 Italian families. Eur Neurol 2000; 44: 31-36.

38. Brusco A., Gellera C., Cagnoli C., et al. Molecular genetics of hereditary spinocerebellar ataxia. Mutation analysis of spinocerebellar ataxia genes and CAG/CTG repeat expansion detection in 225 Italian families. Arch Neurol 2004; 61: 727-733.

39. Illarioshkin S.N., Slominsky P.A., Ovchinnikov I.V., et al. Spinocerebellar ataxia type 1 in Russia. J Neurol 1996; 243: 506510.

40. Onodera O., Aoki M., Tsuda T., et al. High prevalence of spinocerebellar ataxia type 1 (SCA1) in an isolated region of Japan. J Neurol Sci 2000; 178: 153-158.

41. Riess O., Laccone F.A., Gispert S., et al. SCA2 trinucleotide expansion in German SCA patients. Neurogenetics 1997; 1: 59-64.

42. Basu P., Chattpadadhyay B., Gangopadhaya P.K., et al. Analysis of $\mathrm{CAG}$ repeats in $\mathrm{SCA} 1, \mathrm{SCA} 2, \mathrm{SCA} 3, \mathrm{SCA} 6, \mathrm{SCA} 7$, and DRPLA loci in spinocerebellar ataxia patients and distribution of CAG repeats at SCA1, SCA2 and SCA6 loci in nine ethnic populations of eastern India. Hum Genet 2000; 106: 597-604.
43. Tang B., Liu C., Shen L., et al. Frequency of SCA1, SCA2, SCA3/MJD, SCA6, SCA7, and DRPLA CAG trinucleotide repeat expansion in patients with hereditary spinocerebellar ataxia from Chinese kindreds. Arch Neurol 2000; 57: 540-544.

44. Gu W., Wang Y., Liu X., et al. Molecular and clinical study of spinocerebellar ataxia type 7 in Chinese kindreds. Arch Neurol 2000; 57: 1513-1518.

45. Higgins J.J., Nee L.E., Vasconcelos O., et al. Mutations in American families with spinocerebellar ataxia (SCA) type 3: SCA3 is allelic to Machado-Joseph disease. Neurology 1996; 46: 208-213.

46. Stevanin G., Cassa E., Cancel G., et al. Characterization of the unstable expanded CAG repeat in the MJD1 gene in four Brazilian families of Portuguese descent with Machado-Joseph disease. J Med Genet 1995; 32: 827-830.

47. Ikeuchi T., Takano H., Koide R., et al. Spinocerebellar ataxia type 6: CAG repeat expansion in alpha1 A voltage-dependent calcium channel gene and clinical variations in Japanese population. Ann Neurol 1997; 42: 879-884.

48. Storey E., du Sart D., Shaw J.H., et al. Frequency of spinocerebellar ataxia types 1, 2, 3, 6, and 7 in Australian patients with spinoeerebellar ataxia. Am J Med Genet 2000; 95: 351-357.

49. Modi G., Modi M., Martinus I., et al. The clinical and genetic characteristics of spinocerebellar ataxia type 7 (SCA 7) in three Black South African families. Acta Neurol Scand 2000; 101: 177182.

50. Kanazawa I. Dentatorubral-pallidoluysian atrophy or NaitoOyanagi disease. Neurogenetics 1998; 2: 1-17.

51. Subramony S.H., Hernandez D., Adam A., et al. Ethnic differences in the expression of neurodegenerative disease: Machado-Joseph disease in Africans and Caucasians. Mov Disord 2002; 17: 1068-1071. 